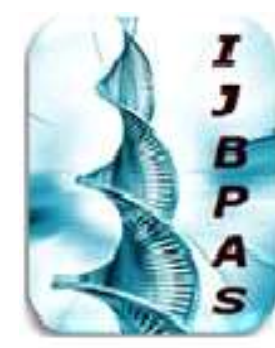

International Journal of Biology, Pharmacy

and Allied Seiences (IJBPAS)

'A B ridge Betusen Caboratory and QRendo'

WwW.jibpas.com

\title{
EXPLORING THE PROBLEMS FACED BY RELIGIOUS MINORITIES REGARDING THEIR LAND ACQUISITION IN DISTRICT KOHAT, PAKISTAN
}

\begin{abstract}
ALAM J ${ }^{1 *}$ AND MUHAMMAD $\mathbf{N}^{2}$
1: Lecturer, Department of Social Work \& Sociology, KUST, Kohat

2: Professor, Department of Sociology, University of Peshawar

"Corresponding Author: E Mail: janalam@kust.edu.pk

Received $1^{\text {st }}$ Sept. 2019; Revised $4^{\text {th }}$ Oct. 2019; Accepted 25 ${ }^{\text {th }}$ Oct. 2019; Available online $1^{\text {st }}$ Feb. 2020

https://doi.org/10.31032/IJBPAS/2020/9.2.4994

ABSTRACT

Minorities in many societies are facing different problems related to their share in both private and community land, inside any area dominated by majority. This research paper is designed to explore the share-holding of land by religious minorities in Kohat, Pakistan. The major objective of this study was to dig out the major factors that can better express their shares in the lands of the study area. This research study used qualitative method, by using grounded theory method for data collection and analysis. To reach to the in-depth of the phenomena, the researchers selected a diverse group of religious minorities by using purposive sampling. A total of 25 respondents were interviewed, including 14 Christians, 6 Hindus, and 6 Sikhs. All interviews were semi-structured; data collection lasted till the saturation of data. Data was analyzed by using grounded theory method, which was completed into two steps namely constant comparison method and theoretical saturation. It is found that the basic needs of religious minorities in community and private lands are; access to residential land, living space problem, provision of Jalsa Gah, absence of children and family parks and absence of proper cemetery. The researchers presented a model by arranging all the identified categories in a diagrammatic model, which provides an easier understanding of share of religious minorities in private and community lands.
\end{abstract}

Key words: Religious minorities; land acquisition; exclusion, marginalization, Grounded theory methods 


\section{INTRODUCTION}

Religious minority are those members of a society, who are minutes in number as well living a vulnerable life. They are the marginalized class who reside in a separate residence which is located in the most vulnerable area of both an urban or a rural area. Though they are also a part of the population, still there needs are not properly addressed, especially their housing and provision of services, so that they live a quality life. In most societies, they do not own any private land as their housing or agricultural land due to their poor socioeconomic position in that society. According to Salway et al. (2007), most of the minorities are living below the poverty line which pushed them to social problems especially poor housing, drug use, health issues, depression, prostitution and crimes.

Kymlicka (2000) found that minorities may be; settled residents such as those members of an ethno-religious group who share similar identity and smaller in number and populated together in a separate area. The second are displaced residents, who are members of any ethno-religious community who are migrated from their place of origin, because of certain social problems, such insecurity and unemployment etc. Hargreaves (2003) also found that, members of a minority group are doing poor jobs and living in poor a residential pattern, as compare to others. By focusing these positions, this research study was designed to explore the actual problems faced by religious minorities in terms of owing lands, who are residing in Kohat, Khyber Pakhtunkhwa Province of Pakistan.

\section{Trejo (1997) and Salway et al.} (2007) reported that a person belonging to any minority group is more susceptible to poorer life chances accompanied by exclusion and poverty. In the light of this, this paper used a qualitative method to discover and explain all the problems related to the acquisition of land by religious minorities in a society dominated by majority. To dig out the actual problems, a diverse group of respondents was interviewed comprised of Christians, Sikhs and Hindus were interviewed through a semistructure interview. The land acquisition related problems were identified through the application of grounded theory method for data collection and analysis. In the end the data analysis, a model is also presented for easier understanding to the researchers and readers of this paper. 


\section{LITERATURE}

The concept of religious minority is socially constructed based on the differences of beliefs among various groups in a society (Waters, 1997). The position of any minority group is based many features such as belief, ethnic, cultural, linguistics, class and status differences, are also attached to it (Capotortio, 1976). Minority is the weaker portion of any population mainly in a nondominant position due to their weaker political, economic and powerless characteristics in the socio-cultural system of any society. Moreover, they are the inferior ones to the rest of population due to their lesser number accompanied by subordinate position in the mainstream society (Nekby $\&$

\section{Rodin, 2007; Moscovici, 1994).}

It is found and reported by various scholars such as Hargreaves (2003), Berry et al. (2002) and Dunn et al. (2007), that religious minorities are the excluded and discriminated member of any society. They are many factors that completely pressurize them to change their livelihoods, living styles or the ways of behavior, which challenges their existing status quo based on the notions of their beliefs. Hence, they are discriminated and excluded to become marginalized class of any mainstream society (Brown, 2000). Besides other problems, minorities in many societies are discriminated and targeted in terms of their housing and acquisition of land. They confined to those houses having poorer conditions, mainly in the form of slums (Graham, 1994). Hence, according to Hargreaves (2003), members of any minority group are living separate residents namely "Ghettos", that is the most ordinary and marginalized type of resident, as compared to the rest of population.

Religious minorities are not only deprived of proper housing in developing countries, but also in developed countries such as England. It is reported that most of the Muslims, the Sikhs and the Hindus in England were probably accommodated in social rented residential areas. Along with this, The Buddhists were also lacking proper housing thus they reside in private rented accommodations. It was reported that that only $2 \%$ of whole of the religious minorities lived rent-free. One of the main reasons behind such marginalization was that certain stereotypes are attached to religious groups; they are unable to properly accommodate themselves (Beckford et al., 2006). The houses of minorities are overcrowded as these are lacking enough number of rooms, with an average number of 3.8, 3.6 and 3.2 people per room (Office of the National Statistics, 2006). 
Similarly, Dunn et al. (2007) and Poynting et al. (2004) also revealed that religious minority groups are considered as culturally inferior and precarious to the mainstream socio-cultural system, because they predict various beliefs differences as compare to the majority. Thus, they are perceived as risky to majority (Franks, 2007). Hargreaves (2003) further reported that minorities are mainly in living in the isolated residents. Their residential pattern is poorest because of the many reasons, such as vulnerable location, over-population, lesser living space and absence of services. Their houses are also lacking essential facilities, such as drinking water, sanitation system, pavement and electricity. Due to these reasons, minorities in many Asian Societies are unable to adjust and locate proper residence for themselves. Thus, they tend to live their lives by wandering from one place to another by keeping themselves away from mainstream society (Kabeer, 2006).

Regarding the acquisition of land, Weller et al. (2001) added that every religious community has its own ways to symbolize its religion, both in terms of material and nonmaterial ways. Among all such symbols, land for religious buildings is of prime importance. But they are not allowed to establish proper places of worship. Beckford et al. (2006) further reported that the religious buildings of the Muslims, the Hindus and the Sikhs in Europe and America, as well as, in many countries of Asia are facing discrimination and improper planning. Due to the prevailing negative perceptions towards other belief groups, most places of worships (i.e. Mosques) are many times attacked by certain intolerant groups in Asia, America and Europe. Because, these people are in frequent fear of the diffusion of Islam, hence, thus they have pressured their Governments to ban the establishment of mosques, such as in Switzerland (BBC News, 2009). Similarly, Germany, being one of the firm supporters of religious pluralism, has also proscribed the establishment of Mosques (Spiegel International, 2008).

Targeting religious minorities and their worship has also been observed in many countries, because people in such societies are violent and non-pluralistic towards other belief groups. Such crimes are committed by both common masses and various terrorist organizations. One such factor could be the absence of security of worship places and the Governments' failure to cope with the aggression of masses against religious minorities (Minority Right Group International, 2002). According to Human Rights Watch (2013), also the religious 
buildings of minorities are more vulnerable to threats in various areas parts of Asia such as India and Pakistan. These have observed several attacks by the extremist groups, because they wanted to close down the places of worship.

\section{METHODOLOGY}

This research study was conducted in District Kohat Khyber Pakhtunkhwa, so that order to explore the land acquisition and share holding by religious minorities in the area. The nature of this study was qualitative, which is in line with the idea of social constructionist approach, revealing that reality is socially constructed by basing that Water (1997) also believed that religious minority is a socially constructed concept. Grounded theory technique was used for data collection and analysis, which was undertaken in to two phases, namely constant comparison and theoretical saturation.

The study area comprised of 32 Union Councils, among which the Christians, the Hindus and the Sikhs are living as religious minorities and the target population of this study. All the respondents were selected purposively. Among these, the respondents consisted of social activists, Church staff, political representatives, employees and religious scholars.

The demographic information is given in the following Table 1.

Table 1: Demographic Information

\begin{tabular}{|c|c|c|c|c|c|c|}
\hline Demographic & \multicolumn{6}{|c|}{ Number of respondents in each strata } \\
\hline \multirow[t]{2}{*}{ Age in Years } & $21-25$ & $26-30$ & $31-35$ & $36-40$ & $41-45$ & $45-50$ \\
\hline & 01 & 04 & 03 & 09 & 05 & 03 \\
\hline \multirow{2}{*}{$\begin{array}{l}\text { Educational } \\
\text { Qualification }\end{array}$} & Primary & Middle & Metric & Intermediate & Bachelor & Master/MPhil \\
\hline & 03 & 02 & 09 & 08 & 01 & 02 \\
\hline \multirow{2}{*}{$\begin{array}{c}\text { Nature of } \\
\text { employment }\end{array}$} & Regular & Contract & Contingent & Daily Wage & Private & Jobless \\
\hline & 09 & 03 & 02 & 03 & 8 & 00 \\
\hline \multirow[t]{2}{*}{ Religious affiliation } & Christianity & Hinduism & Sikhism & & & \\
\hline & 14 & 06 & 05 & & & \\
\hline \multirow[t]{2}{*}{ Marital status } & Married & Unmarried & & & & \\
\hline & 23 & $\mathbf{0 2}$ & & & & \\
\hline \multirow[t]{2}{*}{ Locality } & Rural & Urban & & & & \\
\hline & 04 & 21 & & & & \\
\hline \multirow[t]{2}{*}{ Nature of residence } & Personal & Govt. & Rented & Any other & & \\
\hline & 10 & 04 & 09 & 02 & & \\
\hline
\end{tabular}

The sample of grounded theory method initial sample of this study was Christian consists of Initial sample and theoretical sample as revealed by Charmaz (2006).

The Initial sample of the study comprised those respondents from where the researcher starts data collection, thus, the employees who are working on different positions in Kohat University of Science and Technology, Kohat. However, to get new categories, it was changed after collecting and analyzing the data from 3 respondents. 
The second phase of such sampling is called as theoretical sampling, which included Church and Temple officials, Political and social activists and employees of other organizations.

The researchers conducted face to face interviews with the respondents, by following a proper interview practice and research ethics during each interview session. The collection of data was completed by using a semi-structured interview guide, nonparticipant observations and writing field memos. The interview questions were both close and open ended which changed time and again to get new categories.

The data analysis of this research was carried out by developing open codes, axial codes and selective codes, by reviewing all the coded transcripts, filed note and memos as per the method specified by Corbin and
Strauss (2008). Various labels were assigned each new emerging segment, to complete the data analysis process, till the saturation of data. The researchers continued the process of data collection and analysis till that point beyond which neither any new category could be identified. Such point is called as saturation point by Charmaz (2006). The researchers explored seven different categories coded under the umbrella of one thematic code called as land acquisition. These categories included absence of residential land, high rent, absence of family parks and agricultural land, land for cemetery, living space problems and JalsaGah issues. After completion of data analysis, the emerged categories and subcategories were separated and coded as given in the following Diagram 1.

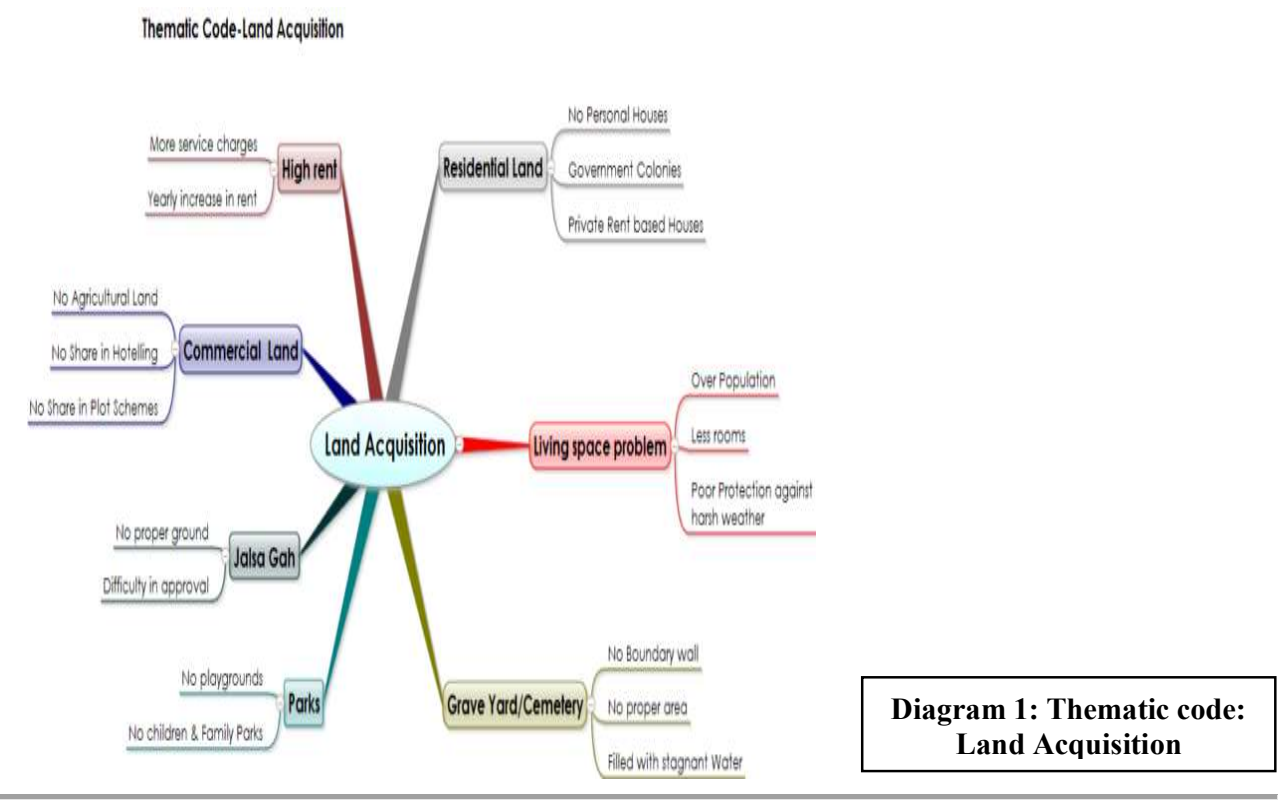


Thematic code: Land Acquisition

Table 2: Thematic code: Land Acquisition

\begin{tabular}{|c|c|c|}
\hline Codes & Categories & Thematic code \\
\hline $\begin{array}{ll}- & \text { No Personal houses } \\
- & \text { Government } \\
\text { Colonies } \\
\text { - } \begin{array}{l}\text { Private rent based } \\
\text { Houses }\end{array}\end{array}$ & Residential land & \multirow{7}{*}{ 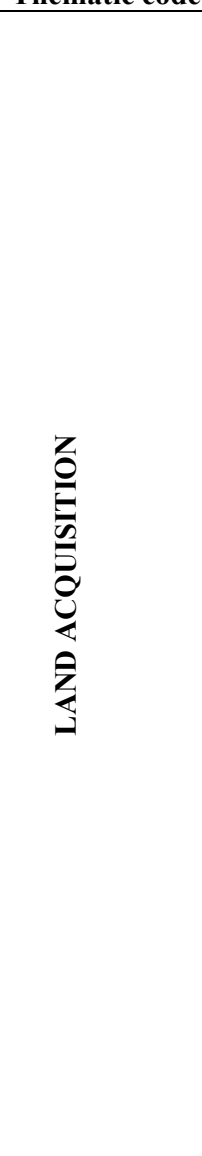 } \\
\hline $\begin{array}{ll}- & \text { Over Population } \\
\text { - } & \text { Less rooms } \\
\text { - } & \text { Poor Protection } \\
\text { against harsh } \\
\text { weather }\end{array}$ & Living space problem & \\
\hline 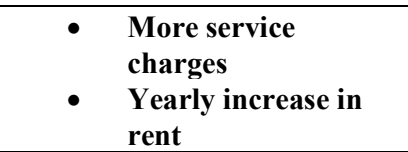 & High rent & \\
\hline $\begin{array}{ll}- & \text { No Agricultural } \\
& \text { Land } \\
\text { - } & \text { No Share in } \\
\text { Hotelling } \\
\text { - No Share in Plot } \\
\text { Schemes }\end{array}$ & Commercial Land & \\
\hline $\begin{array}{ll}- & \text { No Boundary wall } \\
- & \text { No proper area } \\
- & \text { Filled with stagnant } \\
& \text { Water } \\
\end{array}$ & Graveyard/Cemetery & \\
\hline $\begin{array}{ll} & \text { No playgrounds } \\
- & \text { No children \& } \\
& \text { Family Parks }\end{array}$ & Parks & \\
\hline $\begin{array}{ll} & \text { No proper ground } \\
\text { - } & \text { Difficulty in } \\
\text { approval }\end{array}$ & Jalsa-Gah & \\
\hline
\end{tabular}

\section{Explanation}

Possession of land has always been a key indicator of a group's welfare in a society. The distribution of land and opportunity to own land has always been a source of conflict between different groups. Interviewee Masih, Gill stressed that;

"We need land for Jalsa-Gah, housing colony and provision of graveyard, which are the primary needs of the day."
Other Respondents such as Chiragh and Johnson also opined,

"It is very difficult for our families to accommodate because we do not have our own houses. Education is easily available to us but our main problem is housing".

The study finds that there are two major dimensions of land ownership; one is personal ownership, which is important for everyone and which may be in the form of land for agriculture, shop keeping and 
housing, whereas, the other one is a collective or community grounds that means Jalsa-Gah, Parks and more importantly their Cemetery.

The findings given above are comparable with the report of Graham (1994) that in many societies, minorities are targeted also in terms of provision of houses. Their houses are in poor conditions, which are mainly in slums having no proper services, such as sanitation and drinking water etc., which is all a sign of inequality.

The previous studies however, only focused on the housing of religious minorities, but this study presents a new finding by expanding its scope to include overall land acquisitions; the detail of each aspect of their land acquisition is given as follows;

\section{Residential land}

The present study also explored that religious minorities lack personal land for proper housing. Most of them live in rented houses, which are expensive and some members cannot afford them due to their poor economic conditions. A large portion of their salaries is spent in paying rents and bills.

Respondents Treezer confirmed,

"Basic facilities are available to those who are living in Govt. Houses but then they are too small to accommodate the whole family. Those who do not have their own houses are poor and hardly pay the rent and service charges."

Similarly, in developed countries like England, it has been reported that religious minorities are also deprived of their own houses. Most of the Muslims, the Hindus and the Sikhs in England are likely to be accommodated in rented residences. The Buddhists also lack proper housing and they live in private rented accommodation. It was estimated that only $2 \%$ of all the religious minorities live rent-free. However, it has also been reported that certain stereotypes such as extremists/terrorists etc, are labeled which are based on ethno-religious affiliations, due to which the Muslims mainly are compelled to occupy poorer/marginalized houses (Beckford et al., 2006).

\section{Living space problem \& High rents of Houses}

There is no proper family planning among minorities; hence, their houses are mainly over crowded with insufficient living space. There are only two rooms available for every ten or more persons, which make their homes congested. Some of the minorities reside in government colonies; however, they have also been ordered by the 
Governmental authorities to quit them, which have further increased their problem of residence, without having any alternative offered by them. They cannot afford construction due to lack of money and shortage of land. The government is also not giving serious consideration to provide them with proper land or colonies where they can live happily.

Interviewees, namely Kishor disclosed and confirmed,

"We do not have our personal residence; most of us are residing in Govt. colonies; the situation can be improved if we are provided with houses on installments or if we are given loans for constructing houses."

"No, most of us i.e. Religious minorities are poor and we cannot pay the costs of advanced facilities; so, we live in poor houses."

"Yes it is true about them having no proper housing, because no one has paid any attention to them, regarding their housing".

Respondent like Noel opined,

"Another primary demand of our community is that we must be provided with governmental colonies or homes because we do not have living space.
Nowadays we are ordered to quit them but there is no alternative; so, the government needs to provide an alternative before issuing such orders".

Daniel also opined that

"Most of our homes are rented or on lease from the government; there are few facilities; the houses are overcrowded and the rooms are not enough in number/size."

Similar findings were also reported by Beckford et al. (2006), the housing pattern is also poorer for certain minorities, such as Black-Caribbean, Pakistanis and Bangladeshi Muslims. They lack enough number of rooms. Hence, their houses are mostly overcrowded, having large-sized families with average number of 3.8, 3.6 and 3.2 people per room.

\section{Commercial land}

Furthermore, the socio-economic position of any community can be raised if it is provided with commercial land, especially agricultural or fit for any other economic bargaining. However, religious minorities of the study area do not own land that may be used for commercial purposes, so that their socio-economic position may be uplifted. Before this study, no other study has explained the possession and sharing of 
commercial land by the religious minorities.

Minorities are also ignored in Government Plot Scheme.

A respondent Kumar answered,

"Our ancestors are also responsible in depriving us of homes and land. As most of them had been living here from three generations yet they did not bother to buy land and homes".

As confirmed by Kumar and Maraques,

"No, we do not have any hotels or business lands."

It was further confirmed by Sadiq and Hamid,

"I would say, the major need of religious minorities is residence.

However, their status can be uplifted if they are allotted land for agriculture. But, they do not have any land for agriculture or for any other purpose."

These findings are parallel to the findings of Human Rights Watch Asia (2013), which reported that religious minorities in some societies are deprived of owning their land and seizing their property, and they are taken into bonded labor and slavery.

\section{Grave Yard/Cemetery}

Religious minorities share a very negligible portion of community land, such as Graveyard etc. The finding of this study revealed that the provided land is insufficient for a graveyard, even which too has converted into a pool filled with stagnant water, due to no proper management of it. Hence, there is no proper provision of cemetery for the religious minorities, which is a collective land issue concerning all of them.

The response of the respondent Masih was, "I will add that along with other needs, the primary need of our community now a days is the provision of graveyard."

Furthermore, Treezer, and Joel added, "Everybody knows that we have a graveyard issue. Our old graveyard is filled with stagnant water and the boundary wall is broken. We need another graveyard".

Moreover, Gill also confirmed.

"I have witnessed the present condition of our graveyard when once we dug a grave and it got at once filled with water, which is a desecration of the dead body."

Another respondent Masih also opined,

"We are not provided with a graveyard and the old one is always filled with stagnant water, due to the absence of proper drainage system, 
the condition becomes worst during rain. Therefore, it is very important to take notice of it. "

Kumar replied'

"Yes, we have requested the concerned officers so many times, we also met the political leaders, but no one has paid any heed to it. Furthermore, the existing land for cemetery is also insufficient, therefore, it some new land must be allotted for us, for cemetery."

Likewise, the above results the present study, minorities in most of the societies do no own land for proper housing and even they are not given land ownership rights. As there is no clear and authentic data of land shares ethnicity or religious minorities, which have made it more difficult to detect and measure (Isphani, 2016). However, these findings do not highlight the current issues of cemetery related to different other religious minorities.

\section{Parks}

The availability of areas of refreshment, such as family parks and children parks, that add beauty to the life of every individual. However, there are no proper recreational facilities for minorities, where they can freely sit together and enjoy with their family; they can only celebrate their activities at homes or in their specified areas.

A respondent namely Singh explored,

"You know, there are no facilities, like grounds and parks for our families and children; we cannot refresh ourselves like others. For the whole day our families and children are confined to homes."

This unique finding has not been discussed by any other study carried out prior to this research study.

\section{Jalsa-Gah}

Jalsa-Gah is mainly a community land or ground which is used by different groups for political and religious gatherings or for any other purpose in the best interests of their communities. However, religious minorities cannot use it for any such purposes, due to the complicated processes of permissions or due to fear of an attack. Hence, their public gatherings are confined to their religious spots and they cannot hold such meetings openly as done by the majority.

According to the respond made by, Aaric and Malhaw;

"Look! We are not provided with a proper ground like Jalsa-Gah; the grounds are mainly used by the majority, and we are not permitted to 
use it for performing our collective actions."

These findings were also not given in the earlier literature; however, some similarities of them can be found in the report given by the World Bank (2001), when it reports that excluded groups often have a poor share in land-holding and land sharing, not because their economic position but they are also lacking the land shares due to their racial and ethnic background. Minorities are confined only to marginal and unproductive lands (Kabeer, 2006). Hence, they are also more likely to suffer from dispossession of land and less secure claim over these lands.

\section{CONCLUSION}

This paper aimed to explore the position of religious minorities in land acquisition in a majority dominated society. The study used qualitative method by applying grounded theory for data collection and analysis. Respondents of this study were Christians, Hindus and Sikhs of Kohat. These were approached by using purposive sampling technique. Semi-structured interview was used for data collection, till saturation point. It is found that religious minority groups are sharing a poor sharehold in private and community lands.
The paper reveals that the problems faced by religious minorities regarding land poverty, service charges, shortage of living space, over-population, absence of children and family parks, absence of Jalsa-Gah and cemetery. It is further concluded that, religious minorities like other societies, are also sharing poor housing and other land related issues. The factors explored through this paper will be helpful to overcome their problems of land in the study area, and to bring them into the mainstream, so that they may live a prosperous life.

\section{REFERENCES}

[1] Beckford, J., Gale, R., Owen, D., Peach, C., \& Weller, P. (2006). Review of the, Evidence Base on Faith Communities. London: ODPM.

[2] Berry, J., W., Poortinga, Y. H., Segall, M., H., \& Dasen, P., R. (2002). Cross-Cultural Psychology: Research and Applications ( ${ }^{\text {nd }}$ Ed.). Cambridge: Cambridge University Press.

[3] Capotorti, F. (1976). The Protection of Minorities under Multilateral Agreements on Human Rights. Italy: The Italian Year book of International Law.

[4] Charmaz, K. (2006). Constructing grounded theory: a practical guide 
through qualitative analysis. London:

SAGE Publications Ltd.

[5] Corbin, J. M., \& Strauss, A. (2008) Basics of qualitative research: Techniques and procedures for developing grounded theory. New York: Sage Publication Ltd.

[6] Dunn, K., M., Klocker, N., \& Salabay, T. (2007). Contemporary racism and islamaphobia in Australia: racialising religion. Ethnicities, 7, 564-589.

[7] Franks, M. (2000). Crossing the Borders of Whiteness? White Muslim Women Who Wear the Hijab in Britain Today. Ethnic and Racial Studies. 23 (5), 17-29.

[8] Graham, S. (1994). Motivation in African Americans. Review of Educational Research, 64, 55-117.

[9] Hargreaves, G, A. (2003). Immigration, Race and Ethnicity in contemporary France. New York: Routledge 29 West 35th Street.

[10] Human Rights Watch. (2013). In religion's name: Abuses against religious minorities in Indonesia. Retrieved from; www.hrw.org/news/.../Indonesiareligious-minorities-targets-risingviolence
[11] Isphani, F., N. (2016). Purifying the Land of the Pure, Pakistan's Religious Minorities. India: Harper Collins Publishers.

[12] Kabeer, N. (2006). Social Exclusion and the MDGs: The Challenge of 'Durable Inequalities' in the Asian Context. Islamabad: Institute of Development Studies and Overseas Development Institute.

[13] Kymlicka, W. (2000). Minority Rights at Home and Abroad; Citizenship in Diverse Societies. New York: Oxford University Press.

[14] Minority Rights Group International. (2002). Religious minorities in Pakistan. Retrieved from:

http://southas2.w06.wh2.com/Media /NewsDoc/_1787.Pdf

[15] Moscovici, S. (1994). Three concepts: Minority, conflict, and behavioral style. In S. Moscovici, A. Mucchi-Faina, \& A. Maass (Eds.), Minority influence (pp. 233-251). Chicago: Nelson-Hall.

[16] Nekby, L., \& Rodin, M. (2007). Acculturation Identity and Labor Market Outcomes, Retrieved from https://papers.ssrn.com/sol3/papers.c fm?abstract_id $=996410$ 
[17] Office for National Statistics i.e. ONS. (2006). Focus on Religion. Retrieved from; www.statistics.gov.uk

[18] Poynting, S., Noble, G., Tabar, P., \& Collins, J. (2004). Bin Ladin in the suburbs: criminalising the Arab other. Sydney: Sydney Institute of Criminology.

[19] Salway, S., Platt, L., Chowbey, P., \& Harriss, K. (2007). Long-term Illness, Poverty and Ethnicity: Understanding the experiences of sufferers and their families. Bristol: The Policy Press.

[20] Spiegel International. (2008). Go Ahead for Germany's Biggest Mosque. 29 August.

[21] Trejo, S., J. (1997). Why do Mexican Americans earn low wages?. Journal of Political Economy, 105(6), 1235-1268.

[22] Waters, M. (1997). Immigrant families at risk: Factors that undermine chances for success. New Jersey: Lawrence Erlbaum Associates, Inc, Mahwah.

[23] World Bank. (2001). World Development Report 2000-2001: Attacking Poverty. London: Oxford University Press. 